\title{
Occurrence of Holocene Mammalian Remains and Mollusc Shells from Indian Sundarbans with Environment of Deposition
}

\author{
Argha Sarkar* and Prasanta Kumar Sen \\ Department of Botany (Centre for Mangrove Ecosystem Research), \\ Bankim Sardar College, P.O- Tangrakhali, South 24 Parganas, Pin- 743329, West Bengal, India
}

\begin{abstract}
Mammalian remains of Bubalus bubalis, Rucervus duvauceli of swampy forest environment and mollusc shells of mangrove and distinct fresh water ecosystem recovered from the ${ }^{14} \mathrm{C}$ dated Peat, Silty Clay and Alluvial layers exposed at depth from $560 \mathrm{~cm}$ up to surface at Kumirmari and Dakshin Harishpur, south-east of Kolkata, West Bengal of Indian Sundarbans area were studied for animal remains assemblage zonations and analysis of palaeoenvironment during Holocene. Two Local animal remains assemblage zones were proposed for each section studied viz. KUI: Kumirmari and DHI: Dakshin Harishpur. Correlation of local zones of ${ }^{14} C$ dated sediments has revealed two RAZ: Regional Animal remains Assemblage Zones viz. RAZ-I - Bubalus bubalis - Rucervus duvauceli -Telescopium telescopium - Meretrix meretrix - Bankia sp. Assemblage Zone and RAZ-II - Tarebia lineata - Lymnaea (Pseudosuccinea) acuminata f. Patula - Indoplanorbis exustus - Gyraulus convexiusculus - Parreysia sp. - Bellamya bengalensis - Pila globosa - Gabbia orcula - Brotia costula Melanoides tuberculata - Corbicula striatella - Tarebia granifera Assemblage Zone. The environmental phases of deposition of Holocene sediments of Sundarbans, India as revealed from the Regional assemblage zones indicate Swampy mangrove condition during c. 5000-2000 years BP followed by Supra-tidal fresh water condition since c. 2000 years BP.
\end{abstract}

Keywords: Holocene, Indian Sundarbans, Mammalian remains, Mollusc shells, Palaeoenvironment

Received: 08-Dec-2014 Accepted: 13-Dec-2014 Available online: 22-Dec-2014

Corresponding author: Argha Sarkar, e-mail: argha.sarkar09@gmail.com

\section{Introduction}

Documentation of fossil occurrences of extant species is an essential step towards the understanding of the palaeoenvironment of an area. Such knowledge, in turn, results in efforts to preserve the existing fauna (Blois and Hadly 2009, Hadly and Barnosky 2009).

Several workers worldwide studied vertebrate remains from Quaternary deposits (Steadman, 1986; Badam, 2000; Patnaik et al., 2008; Rijsdijk et al., 2009; Tomiya et al., 2011). In India, particularly the mammalian remains of Bovids and Cervids (Gustafson, 1985; Peters, 1988; Biswas and Sonakia, 2001; Schreiber, 2004) were reported in detail along with information from other parts of the world.

Vertebrate remains like unidentified bones (Colvin, 1833; Taylor, 1836), humerus of dog (Taylor, 1837), bones of deer or horse (Brochure, Indian Museum, 1980), Rhino (Brochure, Indian Museum, 1977) etc. were recorded from the Holocene sediments of Bengal basin during the construction works of Fort William and Clive buildings. Ghosh et al. (1992) reported sub-fossil remains of the great one-horned rhinoceros (Rhinoceros sondaicus) in the riverine grass-jungles close to the Sundarbans mangrove swamps deposited about 3000 years ago. These records, however, do not provide significant information for the understanding of the environment of depositional history of the Holocene sediments of Bengal basin.

Invertebrate remains of ecological significance were studied from Holocene sediments of different countries of the world viz., Java (Karny, 1928), Taiwan (Oyama, 1950), Senegal (Vieillefon, 1970; Elouard, 1974; Monteillet, 1974), Peru (Sarma, 1973), Columbia (Cohen and Wiedemann, 1973) and Ecuador (Sarma, 1974). Different types of mollusc shells and specially that of freshwater gastropod were discovered from Holocene sediments of different countries (Govorcin et al., 2001; Jones et al., 2002; Yum et al., 2004; Sumegi et al., 2008; Poirier et al., 2010; Sanko et al., 2010).

The present study deals with the occurrence of mammalian remains of Bubalus bubalis, Rucervus duvauceli and mollusc shells of distinct mangrove and fresh water ecosystem from measured section and chronologically dated Holocene sediments of Indian Sundarbans area. This is the first time that the reconstruction of depositional environment has been attempted through analysis of the animal remains in Sundarbans area of Bengal Basin, India. This study has major implications for interpreting and conserving modern ecosystems and the potential for their re-wilding. 


\section{Materials And Methods}

The mammalian remains and mollusc shells were collected from two locations viz. KUI: Kumirmari near Bagna forest (22 $19^{\prime}$ N Lat. $88^{\circ} 51^{\prime}$ E Long.) and DHI: Dakshin Harishpur, Kachukhali near Gosaba $\left(22^{\circ} 12^{\prime}\right.$ N Lat. $88^{\circ} 55^{\prime}$ E Long.), south-east of Kolkata, West Bengal of Indian Sundarbans area (Fig.1). The subsurface sediments were exposed due to excavation in connection with the 100 days' work of Indian Government for sweet water tank. The mammalian remains (SHV1-SHV5: Sundarbans Holocene Vertebrate 1-5) were cervical vertebra, left radius - ulna, first rib, proximal fragment of rib of Bubalus bubalis and antler fragment of Rucervus duvauceli found at the depth of $540-560 \mathrm{~cm}$ from soil surface at Dakshin Harishpur and several mollusc shells and tubes (SHIV1-SHIV78: Sundarbans Holocene Invertebrate 1-78) found at 0-500 cm depth at Kumirmari and at 0-400 $\mathrm{cm}$ depth at Dakshin Harishpur. The samples were studied in the field and the assemblages of those remains of different locations were noted. Radiocarbon dates so far known from the Sundarbans, India together with the new data was given in TABLE 3 and Figure 2. Sedimentary sequences in time are clearly revealed from the account. Mammalian remains and malacofauna recovered from two locations with their lithology of soil profiles, radiocarbon dating data of the corresponding sediments and present habitat of the animals were plotted in TABLE 1and Fig. 2 for a comprehensive understanding of environment of deposition. The identification of the animal remains recovered was based on their comparison with the bones of Bovidae and Cervidae preserved in Prehistoric Section, Palaeozoology Division and mollusc shells preserved in Mollusc section of ZSI, Zoological Survey of India, Kolkata. The mammalian remains have gained the status of National Zoological Collection as Repository viz. SB1077-SB1081: Sundarbans 1077-1081 in ZSI, Kolkata and the mollusc shells described in this paper are stored in the museum of CMER, Centre for Mangrove Ecosystem Research, Department of Botany, Bankim Sardar College, West Bengal. The environment analysis of the animals recorded from the sediments was made on the basis of their present day habitat and distribution.

\section{II.I Comparison and present day occurrence of vertebrate remains II.I.I Occurrence and ${ }^{14} \mathrm{C}$ age of the sediment}

All the osseous remains were collected from peaty clay sediments at $540-560 \mathrm{~cm}$ depth at DHI and these are of 5090 \pm 210 years BP (Fig. 3)

Bubalus bubalis (Linneaus, 1758) (Fig. 3-1-3-8)

\section{II.I.II Referred Material}

Cervical vertebra (Fig. 3-1, 3-2), Specimen no. SHV1; Left Radius - Ulna (Fig. 3-3, 3-4), Specimen no. SHV2; First Rib (Fig. 3-5, 3-6), Specimen no. SHV3; Proximal fragment of rib (Fig. 3-7, 3-8), Specimen no. SHV4

\section{II.I.III Comparison}

The sub-fossil specimens i.e., cervical vertebrae, left radius-ulna, first rib and proximal fragment of rib resemble about in all proportion to that of preserved specimen of Bubalus bubalis of Prehistoric Section, Palaeozoology Division, ZSI, Kolkata in shape, size and length. Only the spinous process of the sub-fossil cervical vertebrae has grooves on its surface and the centrum is comparatively larger in shape and size than that of the preserved specimen of ZSI.

\section{II.I.IV Distribution and Habitat}

Bubalus bubalis (Swamp buffalo) is more easterly in distribution and inhabit Indochina and Southeast Asia as well as Australia (Macdonald, 2001). This species is found in low lands and swampy places, never in mountains; Assam and Ganges Valley including the Nepal Terai and the Sunderbans (Sclater, 1891).

Rucervus duvauceli (G. Cuvier, 1823) (Fig. 3-9-3-10)

II.I.V Referred Material

Fragment of Antler (Fig. 3-9, 3-10), Specimen no. SHV5

\section{II.I.VI Comparison}

The sub-fossil specimen corresponds in its shape, structural details, presence of tines, branch pattern to that of preserved sample of Rucervus duvauceli of Prehistoric Section, Palaeozoology Division, ZSI, Kolkata from all angles. 
Occurrence of Holocene mammalian remains and mollusc shells from Indian Sundarbans...

\section{II.I.VII Distribution and Habitat}

Rucervus duvauceli (Barasingha or swamp deer) is restricted to India, not extending eastward of the Bay of Bengal or to Ceylon. Along the foot of the Himalaya it embraces the tract from Upper Assam in the east to the Kyarda Dun west of the Jumna, Assam, a few localities in the Indo-Gangetic plain from the Eastern Sundarbans to Bahawalpur, Rohri in Upper Sind (Lyddekker, 1915). It is found in swampland and a variety of forest types ranging from dry to moist deciduous to evergreen. In either forested or open habitats, this species is commonly found near bodies of water.

\section{II.II Comparison and occurrence of invertebrate remains II.II.I Occurrence and ${ }^{14} \mathrm{C}$ age of the sediment}

All the mollusc shells and tubes were collected from alluvium, greyish clay, peaty clay and greyish silty sediments at 0-560 cm depth at KUI and DHI and these are of c. 5000 years BP to present. (Fig. 4)

Bellamya bengalensis (Lamarck, 1822) (Fig. 4-9), Pila globosa (Swainson, 1822) (Fig. 4-10), Gabbia orcula (Frauenfeld, 1862) (Fig. 4-11), Melanoides tuberculata (Muller, 1774) (Fig. 4-13), Tarebia granifera (Lamarck, 1822) (Fig. 4-15), Tarebia lineata (Gray, 1828) (Fig. 4-4), Brotia (Antimelania) costula (Rafinesque, 1833) (Fig. 4-12), Telescopium telescopium (Linnaeus, 1758) (Fig. 4-1), Lymnaea (Pseudosuccinea) acuminata f. patula (Troschel, 1837) (Fig. 4-5), Gyraulus convexiusculus (Hutton, 1849) (Fig. 4-7), Indoplanorbis exustus (Deshayes, 1834) (Fig. 4-6), Parreysia sp. (Benson, 1862) (Fig. 4-8), Meretrix meretrix (Linnaeus, 1758) (Fig. 4-2), Echno fossils of tubes of Bankia sp. (Gray, 1842) (Fig. 4-3) and Corbicula striatella (Deshayes, 1854) (Fig. 4-14).

\section{II.II.II Referred Material}

Shells of specimen no. SHIV19-SHIV21 and SHIV44-SHIV48, SHIV22-SHIV24 and SHIV49SHIV50, SHIV25-SHIV28 and SHIV51-SHIV54, SHIV29-SHIV32 and SHIV61-SHIV62, SHIV70 SHIV73, SHIV1-SHIV6, SHIV55-SHIV60, SHIV36-SHIV38 and SHIV74 -SHIV78, SHIV7-SHIV10, SHIV14-SHIV17 and SHIV65-SHIV66, SHIV11-SHIV13 and SHIV63-SHIV64, SHIV18, SHIV39 and SHIV79-SHIV80, tubes of specimen no. SHIV40-SHIV43 and shells of specimen no. SHIV33-SHIV35 and SHIV67-SHIV69 respectively.

\section{II.II.III Comparison}

The sub-fossil specimen i.e. the excavated mollusc shells and tubes correspond in shape, size and length to that of preserved mollusc shells and tubes of Mollusc Section, ZSI, Kolkata.

\section{II.II.IV Distribution and Habitat}

Tarebia lineata, Lymnaea (Pseudosuccinea) acuminata f. patula, Indoplanorbis exustus, Gyraulus convexiusculus, Bellamya bengalensis, Pila globosa, Gabbia orcula, Brotia costula, Melanoides tuberculata, and Tarebia granifera are fresh water gastropods and Parreysia sp. and Corbicula striatella are fresh water bivalves, occurring in lakes, ditches, ponds and rice fields normally found in stagnant water pools, ponds or tanks (Preston, 1915; Abbott, 1952; Benthem Jutting, 1956). Telescopium telescopium, a gastropod and Meretrix meretrix and Bankia sp. both of the bivalves are common in mangrove swamps along mud flat dominated by Rhizophora, Bruguiera and Ceriops where the water is saline or brackish, also occur on the banks of small ditches or canals with a little flow of water, in Rhizophora forest where the soil is not consolidated (Walter O Cernohorsky, 1972; Chapman, 1976). These mollusc are widely distributed commonly throughout India (West Bengal, Andhra Pradesh, Hyderabad, Assam, Bihar and in other several states) and also in Myanmar, Bangladesh, Sri Lanka, Pakistan, Malaya Archipelago, North and South Africa, South East Asia, Japan, North Australia, Philippines, Red sea, Sumatra etc.

\section{Results}

The faunal assemblages recorded from the two sections DHI and KUI with corresponding litho characters, depth from surface and radiocarbon date were considered to identify the Local Animal Remains Assemblage Zones (TABLE 1; Fig. 2). The distribution pattern of the vertebrate and invertebrate remains in the stratigraphic sequence of each of the sections studied was considered for ascertaining the local zonations. Correlation of the local animal remains assemblage zones was made based on representation pattern of the animal remains assemblages to establish Regional Animal Remains Assemblage Zones of the Holocene sediments of Sundarbans area, India. Zones were proposed following the Code of International Subcommission on Stratigraphic Classification (Hedberg, 1976).

Correlation of the local zones was made for exploring regional stratigraphic zonations. 
Local Animal Remains Assemblage Zone (Fig. 2)

Section KUI. Two Animal Remains Assemblage zones were explored in the litho succession of KUI. The assemblage constitutes of mangrove mollusc shells and fresh water gastropods.

Zone KUI, A-I. Telescopium telescopium - Meretrix meretrix - Bankia sp. Assemblage Zone; Lithology: Grey clay with sand, wood log, leaf cuticles and grey clay with silt; Depth from surface: $200-500 \mathrm{~cm} ;{ }^{14} \mathrm{C}$ data: 1920 $\pm 90-$ c. 2500 years BP; Environment of deposition: Mangrove flat, mangrove swamps with regular inundations.

Zone KUI, A-II. Tarebia lineata - Lymnaea (Pseudosuccinea) acuminata f. patula - Indoplanorbis exustus Gyraulus convexiusculus - Parreysia sp.- Bellamya bengalensis - Pila globosa - Gabbia orcula - Melanoides tuberculata - Corbicula striatella Assemblage Zone; Lithology: Alluvium; Depth from surface: $0-200 \mathrm{~cm} ;{ }^{14} \mathrm{C}$ data: c. 1000 years BP; Environment of deposition: Fresh water swampy condition.

Section DHI. Two Animal Remains Assemblage zones were explored in the litho succession of DHI. The assemblage constitutes of vertebrate remains and fresh water gastropods.

Zone DHI, A-I. Bubalus bubalis - Rucervus duvauceli - Telescopium telescopium - Meretrix meretrix Assemblage Zone; Lithology: Peaty clay; Depth from surface: $540-560 \mathrm{~cm} ;{ }^{14} \mathrm{C}$ data: $5090 \pm 210$ years BP; Environment of deposition: Upland swampy reverian grassland.

Zone DHI, A-II. Bellamya bengalensis - Pila globosa - Gabbia orcula - Brotia costula - Melanoides tuberculata - Indoplanorbis exustus - Gyraulus convexiusculus - Corbicula striatella - Tarebia granifera Assemblage zone; Lithology: Grey clay with sand, wood log and leaf cuticles, peaty clay and alluvium; Depth from surface: $0-200 \mathrm{~cm} ;{ }^{14} \mathrm{C}$ data: c. 600 years BP; Environment of deposition: Fresh water swampy condition.

\section{Regional Animal Remains Assemblage Zone (TABLE 2, Fig. 2)}

Correlation of the Local Animal Remains Assemblage Zones revealed two distinct Regional Animal Remains Assemblage Zones in the Holocene sediments of Sundarbans area, India during 5090 years BP to present.

The Regional Animal Remains Assemblage Zone-I (RAZ-I) representing osseous remains of Bubalus bubalis and Rucervus duvauceli and mollusc shells of Telescopium telescopium, Meretrix meretrix and tubes of Bankia sp. of (KUI. A-I and DHI. A-I) characterise the phase of deposition (Phase-I) as of riverine forests, grassland and estuarine to mangrove swampy environment.

The Regional Animal Remains Assemblage Zone-II (RAZ-II) representing mollusc shells of Tarebia lineata, Lymnaea (Pseudosuccinea) acuminata f. patula, Indoplanorbis exustus, Gyraulus convexiusculus, Parreysia sp., Bellamya bengalensis, Pila globosa, Gabbia orcula, Brotia costula, Melanoides tuberculata, Corbicula striatella and Tarebia granifera can survive only in the fresh water environment. These common fresh water mollusc remains of (KUI. A-II and DHI. A-II) account for the fresh water swampy environmental phase (Phase-II) of deposition.

\section{Discussion}

Several palaeontologists reported various animal remains from quaternary deposits of different countries and predicted the palaeoecology of the study area (Biswas and Sonakia, 2001; Patnaik et.al., 2008; Rijsdijk et.al., 2009 and Tomiya et.al., 2011).

Biostratigraphic zonations and environmental phases of deposition through animal remains analysis were not attempted so far in the Holocene sediments of Bengal basin. Sen and Banerjee, 1984, 1988 and Banerjee and Sen, 1988 reported Reptilian remains, mangrove and fresh water molluscs from different stratigraphic levels of ${ }^{14} \mathrm{C}$ dated Holocene sediments of Bengal basin with remarks on environment of deposition.

The present study based on critical analysis of animal remains of specific environment together with the litho characters and corresponding chronological data of the sediments containing bio forms revealed the animal remains assemblage zones and the environmental phases of deposition of Sundarbans, India during Early Holocene to Recent (TABLE 2 and Fig. 2).

Regression of sea, southwards movement of coastline and seaward advancement of delta in Bengal basin took place due to rapid siltation during 6175-5000 years BP and the estuarine zone existed along Namkhana by c. 4500 years BP (Banerjee and Sen, 1987). The present study area is located at Holocene coastline (c. 4500 years BP) where estuarine ecosystem existed for which it was favourable for those animals to live freely in this swampy area. 
The diverse animal remains recorded during the present study explore two environmental phases of deposition in chronological sequence. Swampy mangrove vegetation marks the initial phase of deposition

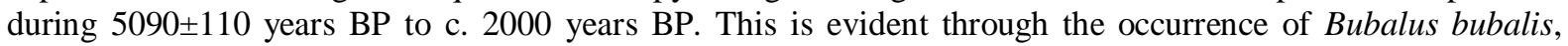
Rucervus duvauceli in the Peat layer just above the grayish silty clay layer at DHI, mollusc shells of Telescopium telescopium, Meretrix meretrix and tubes of Bankia sp. in Peat and Grey clay with mangrove wood $\operatorname{logs}$ at KUI and in Grey clay with mangrove wood logs at DHI. The occurrence of fresh water mollusc shells of Tarebia lineata, Lymnaea (Pseudosuccinea) acuminata f. patula, Indoplanorbis exustus, Gyraulus convexiusculus, Parreysia sp., Bellamya bengalensis, Pila globosa, Gabbia orcula, Brotia costula, Melanoides tuberculata, Corbicula striatella and Tarebia granifera in Grey clay with wood logs and Alluvial layer at KUI and in the Alluvial layer at DHI indicates the next phase of deposition which is characterised as Supra-tidal fresh water condition since c. 2000 years BP. The ecological condition favoured by Bubalus bubalis and Rucervus duvauceli recorded in the peat-layer of DHI is of particular importance as both of these mammalian genera were recorded as extinct in the Sundarbans in the last century due to extensive poaching and man hunting by the British (Sarker,1993). Both of these animals are commonly distributed in wet habitats ranging from riverine forests and grasslands, to marshes and swamps. These habitats are a mixture of tall grasses, rivers and streams, and a scattering of trees and forest types ranging from dry to moist deciduous to evergreen. Such an environment provides them with adequate water for drinking and wallowing, abundant food, and dense cover.

\section{Conclusion}

The occurrence of vertebrate and invertebrate remains from the study site has a significant role with respect to the geological past and present situation. The osseous remains of Bubalus bubalis and Rucervus duvauceli and mangrove mollusc shells of Telescopium telescopium, Meretrix meretrix and tubes of Bankia sp.

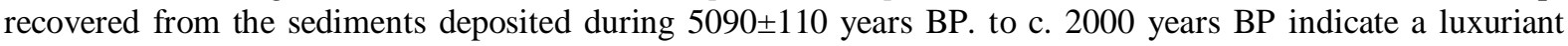
delta front swampy mangrove forest of tropical humid climate during that period in and around the study area. On the other side, rapid siltation, land surface upliftment and shifting of coastline has been occurred resulting fresh water swampy condition prevailing in this area and making it the favourable condition for the colonisation of those fresh water mollusc since c. 2000 years BP.

The geographical distribution of the mammalian genera suggest that though they are extinct now in Sundarbans area even in West Bengal, but they had made their early occurrence in Sundarbans about 5090 years ago. So, it can be suggested that during the Mid-Holocene period they migrated from the northern part of Bengal basin to the swampy environment of Indian Sundarbans, the newly formed delta, having grassland, river shrines nearby to meet their demand of food, water and to sustain their lives. Not only hunting or illegal poaching, but an abrupt ecological stress that has been unfavourable for them has ensured their extinction from Sundarbans area, India.

\section{Acknowledgement}

We are indebted to the Director Dr. K. Venkataraman, Scientist-G; Dr. Gopinathan Maheswaram, Scientist-C, Divisional-in-charge, Palaeozoology Division; Dr. Basudev Tripathy, Scientist-C, Officer-incharge, Mollusc section; Mr. Amit mukherjee, Assistant Zoologist, Mollusc section and Mr. Bulganin Mitra, Scientist-C, Lepidoptera section of Zoological Survey of India, Kolkata, India for their immense help and assistance to identify the animal remains. We convey our cordial thanks to Dr. Naresh Chandra Mehrotra, Former Director and Dr. Chandra Mohan Nautiyal, Scientist-in-charge, Radiocarbon Laboratory, Birbal Sahni Institute of Palaeobotany (BSIP), Lucknow, India for providing radiocarbon data of samples. Our thankful gratitude is conveyed to Prof. Manju Banerjee for her overall guidance throughout the work.

\section{References}

[1]. Blois, J.L., Hadly, E.A. 2009. Mammalian response to Cenozoic climate change. Annual Review of Earth and Planetary Sciences 37: 181-208.

[2]. Hadly, E.A., Barnosky, A.D. 2009. Vertebrate fossils and the future of conservation biology. In G.P. Dietl and K.W. Flessa (eds.). Conservation Palaeobiology: Using the Past to Manage for the Future. Paleontological Society Papers 15: 39-59.

[3]. Steadman, D.W. 1986. Holocene Vertebrate Fossils from Isla Floreana, Galapagos. Smithsonian contributions to zoology 413.

[4]. Badam, G.L. 2000. Pleistocene vertebrate palaentology in India at the threshold of the Millennium. Journal of the Palaentological Society of India 45: 1-24.

[5]. Patnaik, R., Badam, G.L., Murty, M.L.K. 2008. Additional vertebrate remains from one of the Late Pleistocene- Holocene Kurnool Caves (Muchchatla Chintamanu Gavi) of South India. Quaternary International 192: 43-51.

[6]. Rijsdik, K.F., Hume, J.P., Bunnik, F., Florens, F.B.V., Baider, C., Shapiro, B., Plicht, J.V.D., Janoo, A., Griffiths, O., Ostende, L.W.V.D.H, Cremer, H., Vernimmen, T., Louw, P.G.B.D, Bholah, A., Saumtally, S., Porch, N., Haile, J., Buckley, M., Collins, M., Gittenberger, E. 2009. Mid-Holocene vertebrate Concentration-Lagerstätte on oceanic island Mauritius provides a window into the ecosystem of the dodo (Raphus cucullatus). Quaternary Science Reviews 28: 14-24.

[7]. Tomiya, S., Mcguire, J.L., Dedon, R.W., Lerner, S.D., Setsuda, R., Lipps, A.N., Bailey, J.F., Hale, K.R., Shabel, A.B., Barno sky, A.D. 2011. A report on late Quaternary vertebrate fossil assemblages from the eastern San Francisco Bay region, California. Paleobios 30(2): 50-71. 
[8]. Gustafson, E.P. 1985. Antlers of Bretzia and Odocoileus (Mammalia, Cervidae) and the evolution of new world deer. Transactions of the Nebraska Academy of Sciences XIII: 83-92.

[9]. Peters, J. 1988. Osteomorphological features of the appendicular skeleton of African buffalo, Syncerus caffer (Sparrman, 1779) and of domestic cattle, Bos primigenius f. taurus Bojanus, 1827. Z. Säugetierkunde 53: 108-123.

[10]. Biswas, S. and Sonakia, A. 2001. Some fossils of Deer from the Quaternary deposits of Madhya Pradesh, India. Journal of the Palaeontological Society of India 46: 43-49.

[11]. Schreiber, H.D. 2004. Finds of Bubalus murrensis (Bovinae, Mammalia) from the Upper Rhine Valley: a focus to the sedimentological conditions of a Quaternary fluviatile system. $18^{\text {th }}$ International Senckenberg Conference in Weimar.

[12]. Colvin, J., 1833. Bones in the Delta Alluvium. Journal of the Asiatic Society of Bengal II: 649- 650.

[13]. Taylor, T.M. 1836. Note on the progress of the boring in Fort William. J.A.S.B. 5: 374-375.

[14]. Taylor, T.M., 1837. Report. Progress of the boring in Fort William. J.A.S.B. 6: 236-237.

[15]. Ghosh, M., Saha, U., Roy, S., Talukder, B. 1992. Subrecent remains of great one-horned rhinoceros from southern West Bengal, India. Current Science 62 (8): 577-580.

[16]. Karny, H. 1928. Traces of life in the Javanese mangrove formation, a report on the solution of the flysch problem. Paleobiologica 1 (2): $475-480$.

[17]. Oyama, K. 1950. Studies of fossil molluscan biocoenosis. 1. Biocoenological studies on the mangrove swamps with descriptions of new species from Yatuo Group. Rep. Geol. Surv. Japan 132: 1-15.

[18]. Vieillefon, I. 1970. The problem of Quaternary stratigraphic landmarks in casamance (Senegal). Bull. Assoc. Etude. Quotern, Dakar 26: $13-23$.

[19]. Elouard, P. 1974. Ecology of mollusk in Fadioute lagoon (Senegal) and homologous fossils of Mbodiene (5500 years ago). Haliotis 4 (1-2): 153-166

[20]. Monteillet, J. 1974. Quantitative studies of samples of fauna from the recent quaternary of the Saint Louis region (Senegal). Bull. Inst. Fond. Afr. Noire. Ser. A. Sci. Nat. 36 (2): 257-290.

[21]. Sarma, A.V.N. 1973. Evidence of post Pleistocene desiccation in Southwest Ecuador and northern Peru. Geol.Mijub. 52 (1): $33-34$.

[22]. Cohen, A.D., Wiedemann, H.U. 1973. Distribution of and depositional history of some pre- lagoonal Holocene sediments in the Cienaga Granade de Santa Marta Sarma, A.V.N. 1974. Holocene palaeoecology of south coastal Ecuador. Proc. Am. Philos. Soc. 118: 93-134

[23]. Columbia. Mitt .Inst. Colombo Aleman Invest. Cient. Punta de Betin 7: 139-154.

[24]. Govorcin, D.P., Juracic, M., Horvatincic, N., Onofri, V. 2001. Holocene sedimentation in the Soline Channel (Mljet Lakes, Adriatic Sea). Nat. Croat. 10 (4): 247-258.

[25]. Jones, M.D., Leng, M.J., Eastwood, W.J., Keen, D.H., Turney, C.S.M. 2002. Interpreting stable isotope records from freshwater snail shell carbonate: a Holocene case study from Lake Gölhisar, Turkey. The Holocene 12 (5): 629-634.

[26]. Yum, Jong-Gwon, Yu Kang-Min, Takemura, K., Naruse, T., Kitamura, A., Kitagawa, H., Kim, Jong-Chan. 2004. Holocene evolution of the outer lake of Hwajinpo lagoon on the Eastern coast of Korea; Environmental changes with Holocene Sea-level fluctuation of the East Sea (Sea of Japan). Radiocarbon 46 (2): p 797-808.

[27]. Sumegi, P., Gulyas, S., Jakab, G. 2008. Holocene paleoclimatic and paleohydrological changes in Lake Balaton as inferred from a complex quantitative environmental historical study of a lacustrine sequence of the Szigliget embayment. Documenta Praehistorica XXXV, UDK 551.583.7:911.52(439)"63":902.67.

[28]. Poirier, C., Sauriau, P.G, Chaumillon, E., Bertin, X. 2010. Influence of hydro-sedimentary factors on mollusc death assemblages in a temperate mixed tide-and-wave dominated coastal environment: Implications for the fossil record. Continental Shelf Research 30 (17): 1876-1890

[29]. Sanko, A., Vainorius, J., Melešytè, M. 2010. Malacofauna of Holocene freshwater calcareous deposits of Lithuania. Geologija 52, 1-4 (69-72): P. 16-24.

[30]. Macdonald, D. 2001. Wild Cattle and Spiral-Horned Antelope. pp. 530-539 in G Bateman, T Allan, M Salad, eds. The New Encyclopedia of Mammals. New York: Oxford University Press.

[31]. Sclater, W.L. 1891. Cat. Mammalia Ind. Mus. II, pp. 129-130.

[32]. Lyddeker, R. 1915. Cat. Ungulate Mam. Brit. Mus. IV: 95-96.

[33]. Preston, H.B. 1915. Fauna of British India including Ceylone and Burma, Mollusca (Fresh water Gastropoda and Pelecypoda). London. Authority of the Secretary of State for India in Council.

[34]. Abbott, R. Tucker 1952. A study of an intermediate snail host (Thiara granifera) of the Oriental lung fluke (Paragonimus). Proceedings of the United States National Museum 102: 71-116.

[35]. van Benthem-Jutting, W. S. S. 1956. Systematic studies on the non-marine Mollusca of the Indo-Australian archipelago 5. Critical revision of the Javanese freshwater gastropods. Treubia 23(2): 259-477.

[36]. Walter O. Cernohorsky. 1972. Marine shells of the pacific. Vol. II. Pacific publications. Sydney, 61.

[37]. Chapman, V.J. 1976. Mangrove vegetation J. Cramer, Inder A.R. Ganter Verlay Kommanditgesellschaft, Fl- 9490 VA DuZ.

[38]. Hedberg, D.H. 1976. International stratigraphic Guide. New York.

[39]. Sen, P.K. and Banerjee, M. 1984. On the occurrence of reptilian remains in the peat bed of Barrackpore, 24-Parganas, West Bengal. Journal of the Palaeontological Society of India 29: 46-51.

[40]. Sen, P.K., and Banerjee, M. 1988. Palaeoenvironment of Bengal Basin during Holocene in chronological sequence. Geographical Review India 59 (4): 25-38.

[41]. Tryon G. W. 1865. Observations on the family Strepomatidae. American Journal of Conchology 1(2): 97-135.

[42]. Banerjee, M and Sen, P.K. 1987. Palaeobiology in understanding the change of sea-level and coastline in Bengal basin during Holocene. Indian Journal of Earth Science, Special no. Modern Trends in Quaternary Geology 14 (3-4): 307-320.

[43]. Banerjee, M. and Sen, P.K. 1988. Palaeobiology and environment of deposition of Holocene Sediments of the Bengal Basin, India. In Aigner, Jean S. Jablonski, N.G. Taylor, G. Walkder, D. and Pinxian, W. (Eds.). The Palaeoenvironment of East Asia from the Mid-Tertiary. Centre of Asian studies, University of Hong Kong I, pp. 703-731.

[44]. Sarker, S.U. 1993. Ecology of Wildlife UNDP/FAO/BGD/85/011. Field Document N. 50 Institute of Forestry and Environmental Sciences. Chittagong, Bangladesh. 
Figures and Tables

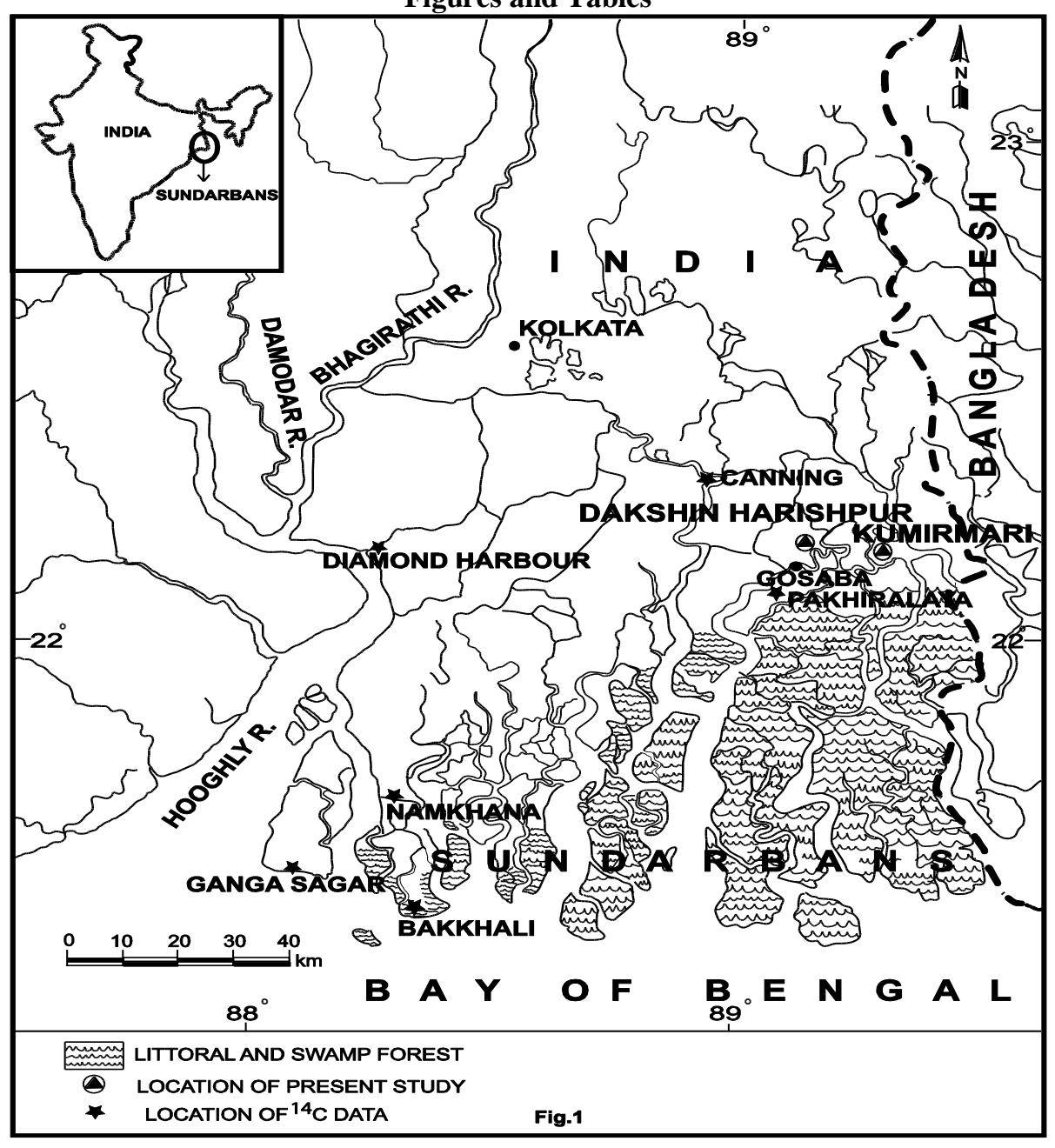

Fig. 1. map of Sundarbans, India showing study areas 


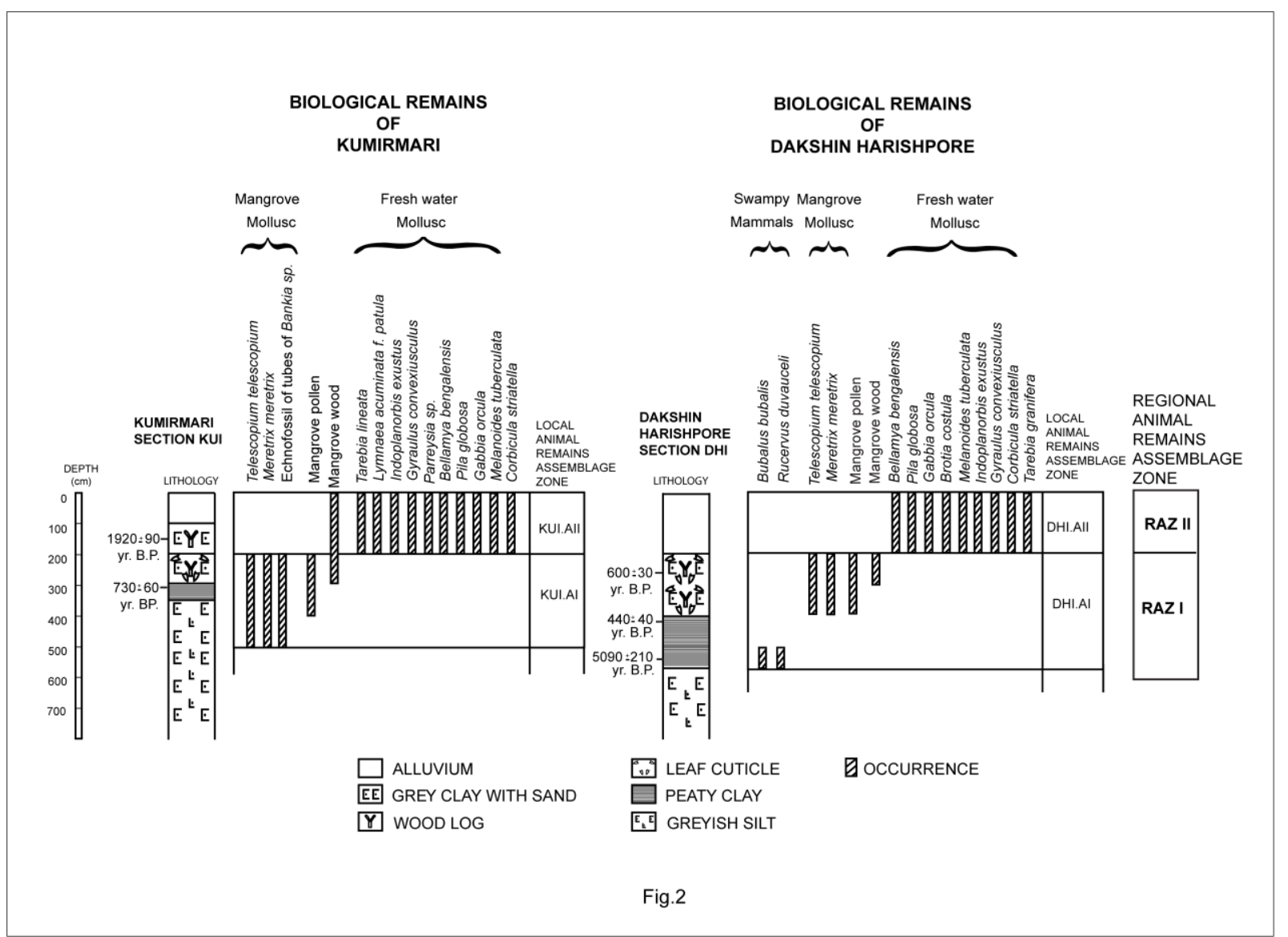

Fig. 2. animal remains assemblage zone of section KUI, Kumirmari and DHI, Dakshin Harishpur at Sundarbans, India

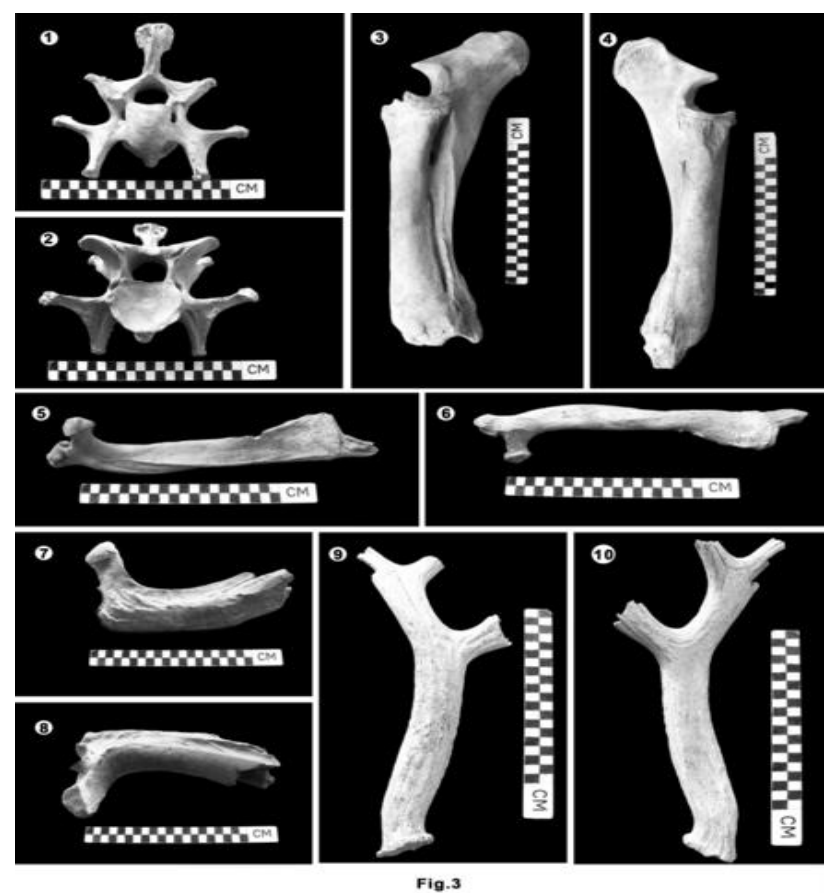

Fig. 3.osseous remains of Bubalus bubalis (1-8) 1. anterior view of cervical vertebrae, 2. posterior view of cervical vertebrae, 3. anterior view of left radius-ulna, 4. posterior view of left radius-ulna, 5. anterior view of first rib, 6. posterior view of first rib, 7. anterior view of proximal fragment of rib, 8. posterior view of proximal fragment of rib; osseous remains of Rucervus duvauceli (9-10) 9. anterior view of fragment of antler, 10. posterior view of fragment of antler. 


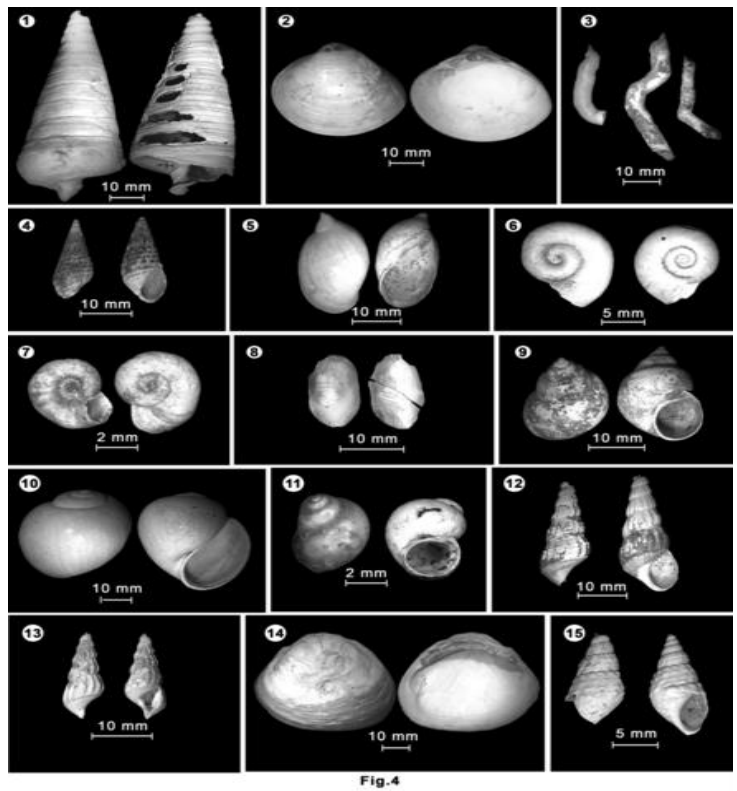

Fig. 4. dorsal and ventral view of mollusc shells of 1. Telescopium telescopium, 4. Tarebia lineata, 5. Lymnaea (Pseudosuccinea) acuminata f. patula, 6. Indoplanorbis exustus, 7. Gyraulus convexiusculus, 8.Parreysia sp., 9. Bellamya bengalensis, 10. Pila globosa, 11. Gabbia orcula, 12. Brotia costula, 13. Melanoides tuberculata and

15. Tarebia granifera; exterior and interior view of mollusc shells of 2. Meretrix meretrix, 14. Corbicula striatella and 3. tubes of Bankia

TABLE 1 - Lithology of sediments, corresponding chronological data and animal remains recovered at Kumirmari and Dakshin Harishpur, Sundarbans, India with their present day occurrence

\begin{tabular}{|c|c|c|c|c|}
\hline Location & $\begin{array}{c}\text { Lithology and } \\
\text { depth }(\mathrm{cm} .)\end{array}$ & ${ }^{14}$ C Date (Yr. B. P.) & Animal remains recovered & $\begin{array}{l}\text { Present day occurrence } \\
\text { of the animals }\end{array}$ \\
\hline \multirow[t]{2}{*}{ Kumirmari } & $\begin{array}{l}\text { Alluvium and Grey } \\
\text { clay, 200-0 }\end{array}$ & $\begin{array}{r}1920 \pm 90 \text { - Present } \\
\text { Bellamya be } \\
N\end{array}$ & $\begin{array}{l}\text { Tarebia lineata, Lymnaea (Pseudosuccinea) } \\
\text { acuminata f. patula, Indoplanorbis exustus, } \\
\text { Gyraulus convexiusculus, Parreysia sp., } \\
\text { ngalensis, Pila globosa, Gabbia orcula, } \\
\text { Melanoides tuberculata, Corbicula striatella }\end{array}$ & Fresh water swamp \\
\hline & $\begin{array}{l}\text { Peaty clay and } \\
\text { Grayish silt, 560-200 }\end{array}$ & $\begin{array}{l}\text { ca. } 3000- \\
1920 \pm 90\end{array}$ & $\begin{array}{l}\text { Telescopium telescopium, Meretrix meretrix, } \\
\text { Bankia } \mathrm{sp.}\end{array}$ & Mangrove swamp \\
\hline \multirow[t]{2}{*}{$\begin{array}{l}\text { Dakshin } \\
\text { Harishpur }\end{array}$} & $\begin{array}{l}\text { Alluvium and Grey } \\
\text { clay, 200-0 }\end{array}$ & $600 \pm 30-$ Present & $\begin{array}{l}\text { Bellamya bengalensis, Pila globosa, } \\
\text { Gabbia orcula, Brotia costula, Melanoides } \\
\text { tuberculata, Indoplanorbis exustus, Gyraulus } \\
\text { convexiusculus, Corbicula striatella, } \\
\text { Tarebia granifera }\end{array}$ & Fresh water swamp \\
\hline & $\begin{array}{l}\text { Peaty clay and } \\
\text { Grayish silt, 560-200 }\end{array}$ & $\begin{array}{l}5090 \pm 210- \\
600 \pm 30\end{array}$ & $\begin{array}{l}\text { Bubalus bubalis, Rucervus duvauceli, } \\
\text { lescopium telescopium, Meretrix meretrix fore }\end{array}$ & $\begin{array}{l}\text { Riverine swampy } \\
\text { est to mangrove swamp }\end{array}$ \\
\hline
\end{tabular}


TABLE 2 - Regional Animal Remains Assemblage Zones (RAZ) of Holocene sediments of Sundarbans, India and corresponding phases of deposition in chronological sequence

\begin{tabular}{|c|c|c|}
\hline${ }^{14} \mathrm{C}$ dates (Years BP) & $\begin{array}{l}\text { Regional Animal Remains Assemblage } \\
\text { Zone (RAZ) }\end{array}$ & Phases of deposition \\
\hline 2000 - Present & $\begin{array}{l}\text { RAZ-II, Tarebia lineata - Lymnaea } \\
\text { acuminata f. Patula - Indoplanorbis exustus - } \\
\text { Gyraulus convexiusculus - Parreysia sp. - } \\
\text { Bellamya bengalensis - Pila globosa - } \\
\text { Gabbia orcula - Brotia costula - } \\
\text { Melanoides tuberculata - Corbicula striatella - } \\
\text { Tarebia granifera assemblage zone }\end{array}$ & $\begin{array}{l}\text { Supra-tidal fresh } \\
\text { water environment }\end{array}$ \\
\hline $5000-2000$ & $\begin{array}{l}\text { RAZ-I, Bubalus bubalis - Rucervus duvauceli - } \\
\text { Telescopium telescopium - Meretrix } \\
\text { Meretrix - Bankia sp. assemblage zone }\end{array}$ & $\begin{array}{l}\text { Swampy mangrove } \\
\text { environment }\end{array}$ \\
\hline
\end{tabular}

TABLE $3-{ }^{14} \mathrm{C}$ dates from Holocene sediments of Sundarbans, India

\begin{tabular}{|c|c|c|c|c|c|c|}
\hline Location & Sample No. & Nature & $\begin{array}{l}\text { Depth from } \\
\text { Surface }(\mathrm{cm} .)\end{array}$ & $\begin{array}{l}{ }^{14} \text { C Age (Yr. B.P. } \\
\pm \text { error) }\end{array}$ & $\begin{array}{l}\text { Calibrated age } \\
\text { (Yr. B.P. } \pm \text { error) }\end{array}$ & References \\
\hline Kumirmari & BS-3435 & Clay & 325 & $810 \pm 70$ & $730 \pm 60$ & Data from present study \\
\hline Kumirmari & BS-3449 & M-Wood & 150 & $1970 \pm 80$ & $1920 \pm 90$ & Data from present study \\
\hline $\begin{array}{l}\text { Dakshin } \\
\text { Harishpur }\end{array}$ & BS-3434 & Clay & 530 & $4450 \pm 170$ & $5090 \pm 210$ & Data from present study \\
\hline $\begin{array}{l}\text { Dakshin } \\
\text { Harishpur }\end{array}$ & BS-3430 & Clay & 410 & $410 \pm 70$ & $440 \pm 40$ & Data from present study \\
\hline $\begin{array}{l}\text { Dakshin } \\
\text { Harishpur }\end{array}$ & BS-3443 & M-Wood & 250 & $590 \pm 70$ & $600 \pm 30$ & Data from present study \\
\hline Namkhana & GrN7137 & Clay & 175 & $3170 \pm 70$ & $3395 \pm 72$ & Gupta 1981 \\
\hline Bakkhali & BS-1159 & M-Wood & 838 & $4710 \pm 120$ & $5427 \pm 136$ & Chanda and Hait 1996 \\
\hline Bakkhali & BS-1191 & E-Clay & 4100 & $6166 \pm 100$ & $7059 \pm 125$ & Chanda and Hait 1996 \\
\hline $\begin{array}{l}\text { Diamond } \\
\text { Harbour }\end{array}$ & PRL 1779 & E-Clay & 2800 & $14460 \pm 350$ & $17726 \pm 485$ & Chanda and Hait 1996 \\
\hline Canning & BS-1160 & M-wood & 3168 & $6250 \pm 140$ & $7140 \pm 163$ & Chanda and Hait 1996 \\
\hline Pakhiralaya & BS-1156 & M-wood & 2230 & $7530 \pm 100$ & $8324 \pm 94$ & Chanda and Hait 1996 \\
\hline Pakhiralaya & BS -1190 & E-Clay & 4980 & $8800 \pm 135$ & $9881 \pm 212$ & Chanda and Hait 1996 \\
\hline Ganga Saga & ar ------- & E-Clay & 90 & $2920 \pm 20$ & $3076 \pm 52$ & Chakroborty 1991 \\
\hline
\end{tabular}

